\title{
Interlibrary Loan Service and National Research
}

Miss Harry is acting chief of the circulation department, and $\mathrm{Mr}$. Ostvold is chief of the reference department, Washington University, St. Louis.

$\mathrm{T}$ HERE WOULD be little justification for another article on interlibrary loans if it were based only on one library's experiences with the traditional problems associated with this service. Writings on the subject, while less numerous now than during the twenties and thirties, have certainly covered the old ground often enough to make further repetition unnecessary. We will attempt, therefore, to go beyond the restating of traditional vexations and suggest different approaches to the problems.

The traditional problems, those which have appeared often enough and long enough to deserve that title, arè almost all of a local and administrative nature and vary widely in importance among institutions and administrators. Is a particular loan request justified or needed? Are there occasions when interlibrary loans should be made for undergraduates? Shall loan requests be honored if the bibliographical information supplied is inadequate? What can be done about borrowers who are habitually late in returning material? Should the service be handled by the reference department or the circulation department? These are, in the main, local difficulties and can be dealt with on that level.

Certain other interlibrary loan problems, however, transcend the individual institu- tion and are part of the broad, over-all research problem of the nation as a whole. Presently available bibliographic aids for locating research material are inadequate and frequently retard the service. Costs of handling the service are increasing, and many libraries are questioning the justice of charging these costs against conventional items of the budget. More emphasis is needed on the importance of interlibrary loan service to the over-all national research program.

Washington University's primary vexation has been a traditional one: funds. By plundering a budgetary item called "Expense Account," interlibrary loans have pushed that item beyond reasonable proportions. Funds that would normally go for such services as rebinding, building upkeep, and supplies are being channeled away to meet express and postage costs. We have, as yet, made no charges of any kind for interlibrary loan service. A liberal policy of encouraging the service has been followed. No geographical boundaries have been drawn. We have not attempted to set up special funds for the service. There is no accounting record showing exact costs of the service. However, the time is near when interlibrary loan costs must be faced as an individual, separate problem of the budget picture. We would like to solve this problem without departing from our liberal stand on the question of providing the research worker freely with the materials he needs. 
In an effort to determine the extent to which this situation exists at other colleges and universities, a brief questionnaire was sent to fifty-one institutions. The returns from forty-eight libraries are shown in the table on p. 149. The six questions contained in the survey, and the replies, will be discussed briefly. Finally, we will summarize some conclusions drawn from the survey.

I. Do you make a charge for interlibrary loan service? If so, what is it?

This question proved to be somewhat ambiguous, unfortunately. The intention was to determine if a charge was made against the borrower, whether library or individual, for any part of the service, including transportation. It is possible that some libraries misinterpreted the question and the results may not be entirely valid. It is interesting to note, however, that a flat rate charge has been adopted at only four institutions, only two of which charge faculty. No library, apparently, charges for its services as a lender. The borrowing library, of course, pays all transportation costs. Yet it would seem justifiable that a lending library make a flat rate charge for its service. Such a charge would, for instance, to some degree compensate the large libraries, that are called on most frequently, for part of their service. One librarian called attention to the cost of setting up books for such an account, and several expressed opposition to the idea of charging for what is basically a library service.

Twenty libraries make some charge for transportation, either to all users of the service, to students only, or to outsiders only. Here, too, several librarians were emphatic in stating that the library should absorb this expense.

It is true that all costs involved in the bibliographic work of locating and verifying materials for interlibrary loans are costs that a library incurs in fulfilling its normal functions. Such costs are often no greater than if the borrower called for the book in person. Wrapping costs, messenger time, transportation charges, and postage might be considered as going beyond normal library responsibilities. No indication was made in any of the returns, however, that any library has attempted to make an itemized cost survey on this basis or on any other. Nor was there any positive statement by any librarian that he felt such a cost survey was needed.

Yet at least eleven ways of handling these costs and apportioning them were noted in the forty-seven surveys returned: i.e., charging transportation costs to all borrowers, to students only, to outsiders only ; charging flat rate to all borrowers, to graduate students only, to outsiders only; charging for costs above a certain level; charging only for special services, such as telephone or telegraph, air mail, etc.

2. Do you find that your interlibrary loan service expense is increasing to the point where it is becoming a burden?

Nine replies stated without qualifications that the service was becoming a burden, either because of cost or time. Sixteen more were in agreement that the service was becoming a burden, but hastened to state that the service was worth it. A number of librarians, including those at larger libraries, vigorously denied that interlibrary loan service is a burden. No librarian suggested reducing or eliminating the service. It appears that interlibrary loan service has thoroughly proved its value.

3. Do you include an item in your budget specifically for the expense of operating an interlibrary loan service?

Only three libraries have set up special funds to handle this service. This would seem to indicate that the service has not yet come of age. And yet an item that at 
most colleges and universities is costing as much as several thousand dollars annually would seem to deserve some sort of special budgetary attention. Some further suggestions on the question of budgets are made in the conclusion of the article.

4. Do you limit yourself geographically in your interlibrary loan service?

As expected, no library definitely refuses to act as lender or borrower because of geographical distances, although some indicated they would prefer such a limitation. One library admitted reluctance to sending books outside the United States, though books are occasionally sent to Canada and Mexico. Another library tries to keep its interlibrary loans within a five hundred mile area.

Since time and transportation cost factors increase with greater distances, geographical limitations on loans would be desirable. But the difficulty of locating material with present union catalog facilities makes this an ideal more to be hoped for than achieved at present. There is, too, the desire to assist libraries in Canada, Mexico, Hawaii, and other remote locations in providing research materials.

5. Do you have a written policy on interlibrary loan service?

Few libraries seem to have devised local regulations to supplement or to interpret the standard A.L.A. code. The code itself is flexible enough, and phrased in general enough terms, to permit local variations. For instance, there may be occasions when undergraduate research work is important enough to justify use of interlibrary loan service. Some libraries have inadequate bibliographical aids to verify authors and titles, but should not be denied service for that reason. Some borrowers refuse to observe time limits and frequently lending libraries are not notified that the loan period should be extended. In most in- stances, it appears, the A.L.A. code can be used as it stands.

6. What was the volume of your interlibrary loans for the fiscal year 1946-47?

Since comparative figures are not available over a number of years, these figures can only indicate the present volume of service. It is obvious that the gross costs of the service, however, if computed for transportation alone, or for transportation plus man-hours, must be considerable. The larger libraries are carrying the heaviest burden, yet some of these institutions were most vigorous in their defense of interlibrary loan service.

This survey was initiated by Washington University Library, as indicated earlier, because interlibrary loan service has become a financial burden. It should be noted that this complaint is directed chiefly against express and postage costs. The library continues to welcome the opportunity to serve other libraries. But it was, frankly, in the hope of finding that some institutions had faced, and in some manner solved, the problem of meeting transportation costs that the survey was made. The results have shown that forty-eight libraries have found at least eleven different ways of meeting the problem, none of them entirely satisfactory.

This library has no desire to complain about the personnel costs to the circulation department, which handles the service here. That is regarded by us and by most libraries, and we feel properly so, as a legitimate function of the library. We agree that librarians could be more careful in putting their requests in proper form, that some libraries and borrowers are tardy in returning materials, that the need for some material requested may be trivial, that books are undoubtedly borrowed for class use or for undergraduates. We agree that heavy volumes should not be requested for the sake of a half-dozen pages that could be repro- 
duced photographically for less than the cost of transportation. We can only try to keep these minor abuses to a minimum. The cost of transportation, however, constitutes a considerable budgetary problem. It is difficult for some libraries to justify charging individuals for transportation, when other libraries absorb the costs. It is difficult for some libraries to convince their administrations that special funds should be allotted for the purpose, when only three out of forty-nine libraries have found it necessary to do so.

Washington University Library has arrived at this impasse: much as it regrets to do so, it will find it necessary to begin assessing borrowers for part or all of the transportation costs unless it can persuade the administration to set up special funds for the purpose. We firmly believe that book funds and funds provided for other services should not absorb this increasing cost. And yet we feel that interlibrary loan service is one of the most positive contributions any research library can make to a national program of research.

Since research is a national problem, interlibrary loan service deserves to be considered on that level. Two general approaches to this problem are suggested. First, it is recommended that college and university libraries participating in interlibrary loan service unite on a common policy in requesting that special funds be provided at each institution for meeting the costs of this service, either transportation costs alone, or transportation plus personnel. It is believed that book funds, departmental funds, supply funds, or salary funds should not be drained to provide transportation costs.

The second approach, more ideal and perhaps more difficult to attain, was suggested some years ago by Dr. J. Christian Bay. If, as suggested above, interlibrary loan service is part of a national research program, the federal government should be urged to extend the franking privilege to libraries. The total research program of the nation consists of innumerable little segments of work being done in the various universities and research institutions. The sum total of this effort is the national research program. The life of the nation depends on it. It would seem eminently proper that the government recognize the importance of the interlibrary loan phase of this program and open the doors wide to the full extension of service that forwardlooking librarians would welcome. The full benefits of interlibrary loans in furthering research will not be felt until research workers, the nation over, have at their command the research facilities of the nation.

There is another aspect of the interlibrary loan problem which can be considered as going beyond the bounds of local administration. It is evident that the nation will be without complete union catalog and bibliographic aids for some years to come. The tremendous accomplishments of the Library of Congress in this direction are still far from complete realization. A partial solution of this lack may be found in the following procedure. Conventional bibliographic citation procedure requires, among other things, that the writer note complete bibliographic data for the works cited in his writings. It fails to require what may easily be of primary importance to the person using the bibliographic citations: the location of the book cited. It is suggested that a program for including in standard bibliographic citation form a symbol to indicate the location of the book cited be initiated. The symbols themselves are available in the Library of Congress handbook, Symbols Used in the Union Catalog of the Library of Congress. It is suggested that, as a part of standard bibliographic citation 
Table

Interlibrary Loan Practices and Services in $4^{8}$ College and University Libraries

\begin{tabular}{|c|c|c|c|c|c|c|}
\hline \multirow[b]{2}{*}{ Library } & \multicolumn{2}{|c|}{ Charge to User } & \multicolumn{2}{|c|}{ Number } & \multirow{2}{*}{$\begin{array}{l}\text { Special } \\
\text { Fund }\end{array}$} & \multirow{2}{*}{$\begin{array}{l}\text { Written } \\
\text { Policy }\end{array}$} \\
\hline & $\begin{array}{l}\text { Flat } \\
\text { Rate }^{1}\end{array}$ & $\begin{array}{l}\text { Trans- } \\
\text { portation }\end{array}$ & Borrowed & Loaned & & \\
\hline Brown & $\mathrm{n}$ & $\mathrm{n}$ & $37^{8}$ & $55^{8}$ & $\mathrm{n}$ & $\mathrm{n}$ \\
\hline Bryn Mawr & $\mathrm{n}$ & $\mathrm{y}$ & 246 & 246 & $\mathrm{n}$ & $\mathrm{n}$ \\
\hline California (L. A.) & $\mathrm{n}$ & $y^{2}$ & 934 & 889 & $\mathrm{n}$ & $\mathrm{y}$ \\
\hline Chicago & $\mathrm{n}$ & $\mathrm{n}$ & 1085 & $3^{8} 34$ & $\mathrm{n}$ & $\mathrm{n}$ \\
\hline Cincinnati & $\mathrm{n}$ & $\mathrm{n}$ & 210 & 514 & $\mathrm{n}$ & $\mathrm{n}$ \\
\hline Colorado & $\mathrm{n}$ & $y^{3}$ & 555 & 460 & $y^{4}$ & $\mathrm{n}$ \\
\hline Columbia & $25 \mathrm{e} \mathrm{pv}$ & - & 1675 & 4218 & $\mathrm{n}$ & $\mathrm{y}$ \\
\hline Cornell & n & $y^{5}$ & 604 & 1260 & $\mathrm{n}$ & $y$ \\
\hline Dartmouth & $\mathrm{n}$ & $\mathrm{y}^{6}$ & 172 & 625 & $\mathrm{n}$ & $\mathbf{n}$ \\
\hline Duke & $\mathrm{n}$ & $y^{5}$ & $106 \mathrm{I}$ & 1780 & $\mathrm{n}$ & $\mathrm{n}$ \\
\hline Harvard & $\mathrm{n}$ & n & 919 & 4320 & $\mathrm{y}$ & $\mathrm{y}$ \\
\hline Indiana & $\mathrm{n}$ & $y^{7}$ & 886 & 985 & $\mathrm{n}$ & $\mathrm{n}$ \\
\hline Iowa & $\mathrm{n}$ & $\mathrm{n}$ & - & - & $\mathrm{n}$ & $\mathrm{n}$ \\
\hline Iowa State & $50<\mathrm{pv}$ & - & $3^{82}$ & 756 & $\mathrm{n}$ & $\mathrm{n}$ \\
\hline $\begin{array}{l}\text { Joint University Libraries, } \\
\text { Nashville, Tenn. }\end{array}$ & n & $\mathbf{y}$ & 853 & 1266 & $\mathrm{n}$ & $\mathrm{n}$ \\
\hline Kansas & $\mathrm{n}$ & $\mathrm{n}$ & $44^{2}$ & 453 & y & $\mathrm{n}$ \\
\hline Louisiana & $\mathrm{n}$ & $y^{5}$ & 455 & 784 & $\mathrm{n}$ & $\mathbf{y}$ \\
\hline M.I.T. & $\mathrm{n}$ & $\mathbf{y}$ & $74^{8}$ & 6533 & $\mathrm{n}$ & y \\
\hline Michigan & $\mathrm{n}$ & $\mathbf{n}$ & 906 & 2691 & $\mathrm{n}$ & y \\
\hline Minnesota & $\mathrm{n}$ & $\mathrm{n}$ & $44^{2}$ & I r 80 & $\mathrm{n}$ & $\mathrm{n}$ \\
\hline Mt. Holyoke & $\mathrm{n}$ & $\mathbf{y}$ & 209 & IIO & $\mathrm{n}$ & y \\
\hline Nebraska & $\mathrm{n}$ & $\mathrm{y}$ & 161 & 405 & $\mathrm{n}$ & $\mathrm{n}$ \\
\hline New York University & $\$ 1^{8}$ & - & I 53 & 301 & $\mathrm{n}$ & $\mathrm{n}$ \\
\hline North Carolina & $\mathrm{n}$ & $\mathrm{n}$ & 1990 & I3I7 & $\mathrm{n}$ & y \\
\hline North Dakota & $\mathrm{n}$ & $\mathrm{y}^{3}$ & 39 & 57 & $\mathrm{n}$ & $\mathrm{n}^{\prime}$ \\
\hline Northwestern & n & $y^{9}$ & 1351 & 1869 & $y^{10}$ & $\mathrm{n}$ \\
\hline Oberlin & $\mathrm{n}$ & $\mathrm{y}^{3}$ & 271 & 462 & $\mathrm{n}$ & $\mathrm{n}$ \\
\hline Ohio & $\mathrm{n}$ & $\mathrm{n}$ & 746 & I335 & 一 & $\mathbf{n}$ \\
\hline Oregon & $\mathrm{n}$ & $\mathbf{n}$ & 1656 & 1022 & $\mathrm{n}$ & $\mathrm{n}$ \\
\hline Pennsylvania & $\mathrm{n}$ & $\mathrm{n}$ & 696 & 1306 & $\mathrm{n}$ & $\mathrm{n}$ \\
\hline Pittsburgh & $\mathrm{n}$ & $y^{3}$ & 319 & 252 & $\mathrm{n}$ & $\mathrm{n}$ \\
\hline Princeton & $\mathrm{n}$ & $\mathrm{n}$ & 845 & 1696 & $\mathrm{n}$ & $\mathrm{n}$ \\
\hline Rochester & $\mathrm{n}$ & $\mathrm{n}$ & 256 & 1078 & $\mathrm{n}$ & y \\
\hline Rutgers & $\mathrm{n}$ & $\mathrm{n}$ & - & - & $\mathrm{n}$ & $\mathrm{n}$ \\
\hline St. Louis University & $y^{11}$ & $\mathrm{n}$ & 171 & 106 & $\mathrm{n}$ & $y$ \\
\hline Smith & $\mathrm{n}$ & $\mathrm{n}$ & 454 & 186 & $\mathrm{n}$ & y \\
\hline Stanford & $\mathrm{n}$ & y & - & - & $y^{12}$ & $\mathbf{y}$ \\
\hline Temple & $\mathbf{n}$ & $\mathrm{n}$ & 353 & $46 c$ & $\mathrm{n}$ & $\mathbf{y}$ \\
\hline Texas & $\mathrm{n}$ & $\mathrm{n}$ & 453 & I 543 & $\mathrm{n}$ & $\mathbf{y}$ \\
\hline Vassar & $\mathrm{n}$ & $\mathrm{n}$ & 147 & 90 & $\mathrm{n}$ & $\mathbf{y}$ \\
\hline Virginia & $\mathrm{n}$ & y & 518 & 754 & $y^{13}$ & $\mathrm{n}$ \\
\hline Washington University & $\mathrm{n}$ & $\mathrm{n}$ & 215 & 220 & $\mathrm{n}$ & $\mathrm{n}$ \\
\hline Washington (State) University & $\mathrm{n}$ & $\mathrm{n}$ & $47^{1}$ & 1678 & $\mathrm{n}$ & $\mathrm{n}$ \\
\hline Washington State & $\mathrm{n}$ & $\mathrm{n}$ & - & - & $\mathrm{n}$ & $\mathbf{y}$ \\
\hline Wellesley & $\mathrm{n}$ & y & 90 & 109 & $\mathrm{n}$ & $\mathrm{n}$ \\
\hline Western Reserve & $\mathrm{n}$ & $\mathrm{n}$ & 179 & 530 & $\mathrm{n}$ & $\mathrm{n}$ \\
\hline Wisconsin & $\mathrm{n}$ & $\mathrm{n}$ & 694 & 900 & $\mathrm{n}$ & $\mathrm{n}$ \\
\hline Yale & $\mathrm{n}$ & $y$ & $4^{16}$ & I 509 & $\mathrm{n}$ & $\mathrm{n}$ \\
\hline
\end{tabular}

$\mathrm{N}=\mathrm{No} ; \mathrm{Y}=$ yes.

1 None of charges shown in this column are made against other libraries or outside borrowers, only against persons within the institution using the service.

2 For "special borrowers."

3 Faculty does not pay.

Special fund for faculty loans to cover transportation.

Borrower pays charges one way.

- Persons outside college pay transportation charges.

$?$ Only if \$ro or more.

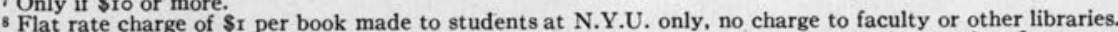

Faculty members allotted $\$ 2$ each per year, pay all transportation costs incurred over that figure; students pay all transportation costs.

ransportation costs.

11 \$r for first title, 25 for each additional title in same unit. Against users within St. Louis University only, no charge to SI for first tit

other institutions.
12 Salary of person handling interlibrary loans comes from a special fund.

is Special $\$ 300$ fund to cover messenger service, addressing labels, wrapping packages. 
procedure, writers be encouraged to include a symbol indicating the location of the books referred to in any bibliographic citation. In the course of a few years, the nation would have innumerable union catalogs in subject form indicating locations of large segments of research material. Since scholars usually get their information on books wanted from such bibliographical citations, they would at the same time have available information as to the location of the book. A suggested bibliographic citation form, including the symbol device for the holding library, might be set up as follows:

Parker, Nathan H. Missouri Hand-book. St. Louis, P. M. Pinckard, 1865. (MoSW)

These two solutions: one a suggestion for a bibliographic device to perform some of the functions of union catalogs; the other, two proposals for relieving libraries of their most pressing problem in the extension of interlibrary loan service, are recommended. Continued international rivalry will undoubtedly require greater integration and extension of research on a national scale. Libraries have a crucial role in this picture, for no research can be adequate without ready access to materials. It is suggested that librarians present the interlibrary loan problems as one aspect of what is a national problem: the problem of promoting research and improving research facilities. It can be presented as such to the federal government in lobbying for extension of franking privileges. It can also be presented as such to research institutions and workers in securing their cooperation in the use of library symbols as a standard part of bibliographic citations.

\section{The Librarian as Teacher}

(Continued from page 123)

the exhibit consists of four or five questions which are suggested as fundamental to the problem. Although a staff member assumes final responsibility for the exhibit, the student assistant obviously must scan the material available to make a preliminary selection and to suggest pertinent questions.

Finally there is the large class of student jobs which are of educational value chiefly because they help develop good personal qualities, sense of responsibility, habit of carrying work through to completion, ability to organize work, etc. These should, of course, accompany anything else the student learns. There are some types of work which are particularly helpful in this respect-for example, service at a reserve desk where the student may be left in charge at certain periods. The development of these qualities in the student assistant depends upon good personnel practice in the library and the teaching ability of the staff member who supervises the student's work.

The opportunities open to the librarian as a teacher in the library are almost limitless. It remains only that he accept and welcome these opportunities and participate actively in this role. 